\title{
COLLECTION AGENCIES AND THE COURTS
}

\author{
Thomas E. Butterfield, JR.*
}

The past few years have witnessed a concerted drive in the courts by the legal profession against cerain activities of collection agencies. Numerous actions have been instituted by bar associations or by individual lawyers to restrain the unauthorized practice of law by the agencies, or to terminate the existence of corporate agencies because of such unauthorized practice. The "lay" collection agency is by its very nature precluded from the practice of law, an activity reserved to the members of the legal profession. The form of the agency, whether individual or corporate, appears to bear little weight in the decisions. Practice by the corporate agency is merely subject to the additional sanction of the rule that "a corporation cannot practice law." ' Under neither form has any agency even contended that it was entitled to practice law. ${ }^{2}$ If, however, the agency is maintained by a lawyer or by a legal firm, it is not vulnerable to such attack, for it is clear that a lawyer may specialize in collecting claims whether or not suit is necessary thereon, ${ }^{3}$ and may forward claims to another lawyer for collection. In conducting such work, the lawyer is subject only to the usual professional standards governing the attorney in the practice of law. It is for this reason that the great majority of the cases deal with the activities of lay agencies.

The point upon which most of the cases turn is whether or not the questioned activity of the lay agency constitutes the practice of the law. Of great importance in any consideration of the cases is an inquiry into the plan of operations under which the agency conducts its collection business. For a close analysis of the procedure employed by the agency is characteristic of all the decisions in this field.

Chronologically the first phase of the agency's activities in the collection of claims

- A.B., x935, Lehigh University. Now a member of the third year class in the Duke University Law School. Editor, Duke Bar Association Journal.

${ }^{2}$ Pcople ex rel. Los Angeles Bar Ass'n v. California Protective Corp., 76 Cal. App. 354, 244 Pac. ro89 (1926); Midland Credit Adj. Co. v. Donnelley, 219 Ill. App. 271 (I920); In re Co-Operative Law Co., 198 N. Y. 479,92 N. E. 15 (1910).

"Two decisions have gone so far as to permit agencies to act themselves as "attorneys" in justice of the peace courts. Representing a minority view, these decisions are based upon special statutes, and upon the judicial holding that a justice of the peace court is not technically a court. United Securities Corp. $v$. Pantex Pressing Mach., 98 Colo. 79, 53 P. (2d) 653 (x935); Rehm v. Cumberland Coal Co., x69 Md. 365, I8I Atl. 724 (1935). Contra: Depew v. Wichita Ass'n of Credit Men, I42 Kan. 403, 49 P. (2d) I04I (1935), cert. denied, 297 U. S. 7ro (1936); State ex rel. Freebourn v. Merchants' Credit Service, 66 P. (2d) 337 (Mont. I937); State ex rel. Dist. Atty. v. Lytton, I Io S. W. (2d) 313 (Tenn. I937).

${ }^{3}$ In re Swihart, 42 S. D. 628 , 177 N. W. 364 (1920). 
solicited by it is the dunning of the debtor. Ordinary dunning may take the form of personal contact or of written communications. The effectiveness of these forms is dependent upon persuasion or intimidation of the debtor. The latter method has frequently run afoul of the law. By some agencies debtors are intimidated by the use of fearsome legal-looking documents, "prepared with generous use of large black type, large red type, and glaring underscoring of legal phrases, with very conspicuous seals attached." 4 Various instruments are addressed to the debtors-denominated variously as "final notice," "garnishee demand and supplementary notice," "notice to employer," etc. The law is held up as a bogey for the oppression of debtors. Such simulation of judicial process has been generally condemned as unlawful practice of the law, ${ }^{5}$ and is frowned upon by reputable agencies. The use of such instruments by attorneys for purposes of collection has been also condemned as unprofessional. ${ }^{3}$ A few courts have held the mere threat by an agency to bring suit against the debtor if he does not pay, to be a usurpation of the function of the lawyer." Influential, however, in one of these decisions was the fact that the agency used a letterhead reading "attorneys all over Canada and United States." It is possible also, though not apparent, that, in two of the cases, the manner of the threat, as well as the mere threat itself, may have lent weight to the decisions. It is to be doubted that the courts will apply stringenly the rule that a threat by an agency to institute suit constitutes practice of the law. One case points out that the separation of legitimate from unlawful dunning methods may be an exceedingly difficult factual question. ${ }^{8}$ It is diffcult, for example, to say with certainty how much red ink or how many seals are permissible in the ordinary dunning letter without transgressing the rule forbidding simulation of legal process. Mere dunning is not practice of the law, ${ }^{0}$ but it appears from the decisions that an agency must be very chary in its use of threats to institute suit against the debtor.

Where its dunning methods are unobjectionable, an agency engaging in the mere solicitation and collection of claims has generally been free from attack. For the courts hold quite generally that solicitation and collection of claims "without resort to the courts" is a legitimate pursuit and does not constitute practice of the law. ${ }^{10}$

'State Bar v. Retail Credit Ass'n, I7o Okla. 246, 248, 37 P. (2d) 954, 956 (1934).

'Berk v. State, 225 Ala. 324, I42 So. 832 (1932), 84 A. L. R. 740 (I933); State ex rel. Frecbourn v. Merchants' Credit Service, supra note 2; State Bar v. Retail Credit Ass'n, stipra note 4. Sce cases collected in Brand, Unauthorized Practice Decisions (1937) at 794.

'In re Davis, I68 Minn. 6, 209 N. W. 627 (1926); In re Swihart, supra note 3.

"Harman v. Associated Retail Credit Men, Brand, op. cit. supra note 2, at 416 (Sup. Ct., D. C. 1935) (The court here approved an agreement by the agency "that it will not attempt to make collection of any such account by means of threats of legal action or threats that it will place such account with any attorney at law either directly or indirectly."); State ex rel. McKittrick v. C. S. Dudley \& Co., 102 S. W. (2d) 895 (Mo. I937); Goodman v. Provident Credit Co., Brand, op. cit. sttpra at 426 (Ct. of Common Pleas, Ohio 1935); Le Barreau de Quebec v. Merchants' Credit Adj. Bureau, Rap. Jud. Quebec 66 C. S. 235 ( 1927$)$.

"In re Sandborg, Brand, op. cit. supra note 2, at 602 (Dist. Ct., Minn. 1930) ("Apparently this respondent tried to get as close to the line as was supposed to be safe; I think it was crossed.")

${ }^{9}$ Washington St. Bar Ass'n v. Knapp, Brand, op. cit. supra note 2 at 451 (Super. Ct., Wash. 1935).

${ }^{10}$ Neander v. Tillman, 232 App. Div. I89, 249 N. Y. Supp. 559 (193I); State ex rel. McKittrick v. C. S. Dudley \& Co., supra note 7; Public Service Traffic Bureau v. Haworth Marble Co., 40 Ohio App. 
There is, however, some recent support for the view that neither a layman nor a corporation may engage in any phase of the collection business. Statutes in Alabama $^{11}$ and in Rhode Island ${ }^{12}$ apparently include the business of collecting claims by demand or negotiation out of court in the definition of practice of law, thereby making the conduct of such business by a layman or corporation unlawful. To the same effect are some orders issued by the Supreme Judicial Court of Massachusetts at the instance of the attorney general, restraining generally the conduct of a collection agency business by laymen. ${ }^{13}$ The bulk of the cases involve activities of the agencies somewhere between these two extremes.

The decisions are all comparatively recent and illustrate in most instances a gradual curtailment of the activities of the collection agencies. For very practical reasons the agencies have been unwilling to restrain their activities to the mere collection of claims by ordinary dunning methods. It is argued that the most lucrative operation of the collection business entails offering the public a complete service. ${ }^{14}$ To gain customers an agency must be able to tell the business man that for a certain percentage of the recovery the agency will collect all of his claims which are collectible. It would be an unattractive proposition to the merchant for the agency to say that the claims which it could not collect without suit would be returned to the creditor, even though only a small charge were made. Compensation of the agency is almost necessarily contingent. To make no charge for all claims on which suit was necessary would be unprofitable. The creditor might still decide that he might better have gone to a lawyer in the first place. Thus it is obvious that there is a strong incentive for the agency to retain some control of all claims till final recovery, whether collected with or without suit.

Probably the first collection business restrained was that conducted by a corpora-

225, I78 N. E. 703 (I93I); State v. James Sanford Agency, I67 Tenn. 339, 69 S. W. (2d) 895 (1934). But see Meisel \& Co. v. National Jewelers' Bd. of Trade, 90 Misc. I9, 28, I52 N. Y. Supp. 913, 9 I9 (19I5).

12 ALA. CODE (Michie, Supp. 1932) \$6248-“Only such persons as are regularly licensed have authority to practice law. For the purposes of this section, the practice of law is defined as follows: Whoever ... (d) As a vocation, enforces, secures, settles, adjusts, or compromises defaulted, controverted or disputed accounts, claims or demands between persons with neither of whom he is in privity or in the relation of employer and employee in the ordinary sense; is practicing law." In Berk v. State, supra note 5, this act was declared constitutional and was held to apply to a collection agency which contracted to turn claims over to its lawyer when it deemed suit necessary thereon, and which collected the attorney's fee from the debtor. See Kendrick v. State, 218 Ala. 277, 120 So. 142 (1928). Contra: Tex. Gen. Laws (1933) c. $238, \$ 2$. Subdivision (c) of this act is identical with (d) in the Alabama act, supra, but is qualified as follows: "provided that subdivision (e) hereof shall not prohibit any individual, company, corporation or association, owning, operating, managing, or controlling any collecting agency .. . from ... collecting, securing, settling, adjusting or compromising, out of court, defaulted, controverted, or disputed accounts, or claims growing out of contractual relations. . .."

${ }^{12}$ R. I. Püb. Laws 1935 c. $2190, \$ 45$ is substantially the same as subdivision (d) of the Alabama act, supra note II. It excludes, however, from its operation non-profit-sharing credit corporations or associations engaged in the collecting and adjusting as incidental to their main purposes, contract claims of their own members; "provided, however, that if the aid of any court is to be invoked on such a claim, the same shall be turned back to the creditor-member for reference to his own attorney at law." Held constitutional in Creditors' Service Corp. v. Cummings, I90 Atl. 2 (R. I. I937).

${ }^{13}$ (1935) I Unauth. Prac. News, No. I2, p. 6.

"Dudley, The Collection Agency and the Public Interest (1935) 40 Cox. L. J. 274. 
tion composed of lawyers, whose members brought suit on claims solicited by the corporation. ${ }^{15}$ This corporation was dissolved by an early application of the rule that a corporation cannot practice law. A similar set-up found a lay agency maintaining its own law department through which it performed the services of an attorney when suit was necessary on solicited claims. Such an agency has been held to be undertaking the practice of law, whether the law department be maintained on a salary or on a commission basis. ${ }^{16}$ The Illinois court expresses its difficulty in seeing how the agency could maintain such a department "without practicing law." The same result was reached where a partnership carried on a collection business. ${ }^{17}$ Claims were solicited by the lay members of the firm and suits were brought thereon by the attorney member. To the court this scheme savored too much of champerty and maintenance. The agreement for a split of the fees between the legal and the lay members of the firm was held void as against public policy. Also void as against public policy was an arrangement between an agency and an attorney whereby routine collections were to be handled by the agency and collections requiring suit were to be handled by the attorney. ${ }^{18}$ This was described as an elusive attempt by the agency "to practice law under the disguise of its attorney associate." Such schemes as these have never been in widespread use by the reputable collection agencies.

Various other business practices generally followed by the agencies have also been held illegal. Under one widespread plan of operation, the agency solicits claims from creditors under an agreement whereby the agency is to collect the claim. The agency retains a certain percentage of the recovery if the claim is collected without suit, and an increased percentage if suit is necessary. The ordinary claim is collected by the agency without resort to the courts. If suit appears necessary, the agency selects to handle the matter an attorney who receives as compensation for his services the major percentage of the agency's commission, plus a suit fee if suit is actually brought. This scheme has generally been held to constitute practice of the law wherever brought to the attention of the courts. ${ }^{19}$ In In re Ripley ${ }^{20}$ the collection agency agreed to "enforce, secure, settle, adjust and compromise" claims of its clients. This was condemned as a contract to furnish legal services. The injunction in Depew $v$. Wichita Ass'n of Credit Men ${ }^{21}$ restrained specifically only the splitting of fees between the agency and the attorneys retained by it to prosecute its clients' claims. In view of the fact that such practice was then apparently permitted under Canon 34 of

${ }^{15}$ In re Co-Operative Law Co., supra note $\mathrm{I}$.

${ }^{16}$ Creditors Nat'l Clearing House v. Bannwart, 227 Mass. 579, 116 N. E. 886 (1917); State ex rel. v. Retail Credit Men's Ass'n, 163 Tenn. 450, 53 S. W. (2d) 918 (193I).

${ }^{17}$ Waychoff v. Waychoff, $309 \mathrm{~Pa} .300,163$ Atl. 670 (1932).

${ }^{13}$ Midland Credit Adj. Co. v. Donnelley, stupra note r. Hicks and Katz, Prattice of Law (1931) $4 \mathrm{I}$ YALE L. J. 69, 88.

${ }^{10}$ Depew v. Wichita Ass'n of Credit Men, supra note 2; In re Shoe Mfgts. Protective Ass'n, 3 N. E. (2d) 746 (Mass. 1936); In re Ripley, r91 Atl. 918 (Vt. 1937).

${ }^{3}$ Supra note 19.

${ }^{21}$ Supra note 19. 
the American Bar Association Canons of Ethics, ${ }^{22}$ the court placed reliance on Canon 35 proscribing dealings with intermediaries. In a Massachusetts case, ${ }^{23}$ the court singled out as unauthorized practice the fact that the agency determined whether or not legal proceedings should be instituted and exercised its full discretion as to settlements and compromises of claims. Basic in the decision of these cases was the fact that the lawyer employed by the collection agency to prosecute claims solicited by the agency was the agent not of the creditor but of the agency. All correspondence passed through the hands of the agency and in many cases the "client" never knew who his attorney was. The recovery was always forwarded to the creditor by the agency. Such intervention by the agency has been condemned on the ground that it destroys the confidential and fiduciary relationship which should exist between attorney and client. A dictum in one case intimated that it might be permissible for the agency to engage a lawyer for the creditor, provided the creditor actually became a client of the lawyer. ${ }^{24}$

Several recent cases illustrated attempts by the agencies to come within the scope of the above dictum. In a Virginia case ${ }^{25}$ the agency specified in all its correspondence that it was merely the agent of the creditor to select the attorney and that the direct relation of attorney and client was created between the attorney who handled the suit and the creditor. The court, in holding the agency engaged in unauthorized practice of the law, looked beyond the technical relation of attorney and client created by the contract of the parties to the practical control exerted by the agency. It was found that the agency "selects the lawyer, employs him, fixes his compensation and shares therein, prescribes the term of his employment, and controls and directs his actions, even to the point of discharging him if it sees fit." The same procedure was used by the agency in a Missouri case, ${ }^{26}$ with two additional modifications: I. The agency requested its creditor-clients, when it became necessary to place the claims in the hands of an attorney, to select attorneys of their own choice. It was found, however, that under this arrangement the creditors did not avail themselves of the privilege and that the agency selected "nearly all the attorneys to whom claims were sent for collection." 2. The attorney's compensation was fixed at a certain percentage of the recovery, rather than upon the basis of the agency's commission. Here too the court enjoined the continued conduct of such business by the agency, finding that in fact the attorney was the agent of the collection agency and not of the creditor. The court's conclusions are of great significance:

2 This canon was amended in 1937 , and as now worded does not permit fee splitting of any sort between attorney and layman. Contra: I8 PA. Stat. ANN (Purdon, x930) $\$ 2507$ “... but the established custom of sharing commissions at a commonly accepted rate upon collection of claims between a collection agency and an attorney or attorneys at law is not prohibited hereby."

${ }^{2}$ In re Shoe Mfgrs. Protective Ass'n, supra note I9.

24 State ex rel. v. Retail Credit Men's Ass'n, 163 Tenn. 450, 464, 43 S. W. (2d) 918, 922 (I93I) “. . . the defendant is free to engage for the retail merchants and others about the collection of their claims as many attorneys as these customers authorize. The lawyer, however, must be engaged to represent the merchant whose claim is turned over. The merchant must become a client of the lawyer."

$\approx$ Richmond Ass'n of Credit Men v. Bar Ass'n, I89 S. E. I53 (Va. 1937).

${ }^{30}$ State ex rel. McKittrick v. C. S. Dudley \& Co., supra note 7 . 
"We therefore conclude that the respondent has the right to collect debts for others provided it does not employ an attorney or promise to employ one, or threaten the debtor with suit if he does not pay. If collections cannot be made without the services of an attorney, the respondent should return the claim to the creditor who should be free to select and employ his own attorney. The respondent should not engage directly or indirectly, in the business of employing an attorney for others to collect claims or to prosecute suits therefor, nor have any interest in the fee earned by the attorney for his work."27

In one Tennessee case only has the court upheld the terms of the parties' contract giving the agency the right to engage an attorney, as agent for the creditor. ${ }^{28}$ The court held that the collection agency by contract with its clients might upon their direction select and employ an attorney to represent the client in any court proceeding found necessary to collect the claim, and might fix the attorney's compensation. "Employment of a lawyer by the agent in behalf of the patron would create the relation of attorney and client, as between the patron and the lawyer. . . . Control of the claim would be transferred to the lawyer." The meager facts in this case do not give us the details of the procedure used by the agency. It is clear however that the agency is enabled by this decision to give a form of complete collection service to its clients, which would appear to be precluded by the Virginia and Missouri cases.

As yet unpassed upon by the courts is a procedure under which the agency limits its contract with creditors to an engagement to collect claims by permissible dunning methods. If such methods fail of collection, the agency will send to the creditor the names of several lawyers, from which the creditor may select one lawyer to prosecute his claim. The creditor offers to engage the attorney, an offer which is communicated to the attorney by the agency. If the attorney accepts the offer, he has made a contract with the creditor, and not with the agency, which from this point on is out of the picture. The work of the agency has saved the creditor some trouble in the selection of an attorney, and still the agency has not employed the attorney itself. The legality of such a plan of operations would not appear to be precluded even under the Missouri decision.

The agencies have also resorted to other means of rendering the public a complete collection service. A formally perfect device is available in the assignment method. The agency secures claims for collection in the usual manner and, if it appears that suit is necessary to collect the claim, the agency takes an assignment thereof from the creditor. As legal title holder the agency then brings suit on the claim in its own name. From the ultimate recovery the agency deducts a substantial percentage, out of which it pays court costs and attorneys' fees and takes its own commission. The balance is returned to the creditor. This practice has been upheld in California ${ }^{20}$ and in Washington. ${ }^{30}$ The California court held the agency was not engaged in the practice of law, relying upon a statute which recognized the right of collection

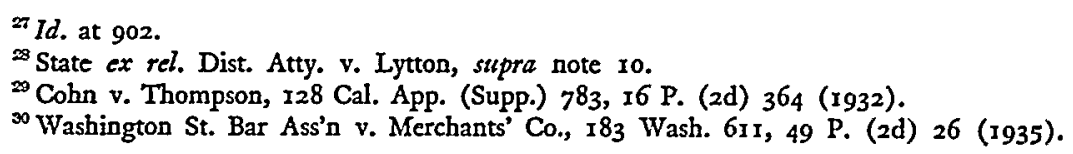


agencies to do business, including "obtaining in any manner the payment of a claim"; ${ }^{11}$ and upon the absoluteness of the assignment upon its face. The court felt that the practice had been "so long recognized . . . both by statute and decision" that it could not be against public policy. The Washington court relied on statutes permitting suit by the assignee of a chose in action ${ }^{32}$ (that the assignment was for collection was held to make no difference under the statute), and recognizing the right of a collection agency to do business. ${ }^{33}$ Four other courts, however, have reached the opposite result. A Virginia collection agent sued in propria persona on a claim assigned to him by a client. On motion of the defendant and upon the authority of a Virginia statute, ${ }^{34}$ the court dismissed the complaint. ${ }^{35}$ An Illinois court held that the agency was engaged in the practice of law, regarding the assignment as a "fraud and a sham and merely subterfuge to enable ... [the agency] to commence the suit in its own name."36 A Tennessee court, taking the same view, holds that, although if taken singly the assignment contracts might be unobjectionable, nevertheless when they constituted a customary practice they were to be condemned as a device to evade the laws relating to practicing law. ${ }^{37}$ A Montana court has recently reached the same result on the ground that the agency as assignee for collection was not the real party in interest. ${ }^{38}$ Hence, as the agency brought the suits in a representative capacity, it was engaged in the practice of law. These decisions illustrate the courts' unwillingness to sanction any device which will enable the agency to control the suit on claims solicited by it for collection. The same result has been reached by statute. ${ }^{39}$ The New York statute has been applied to a subsidiary corporation which took assignments of notes from its parent corporation for the purpose of bringing suit thereon, even though there was no solicitation by the subsidiary. ${ }^{40}$

As a natural concomitant of their ordinary claim work the agencies have occasion to file claims in bankruptcy. In connection with this subject also, the question of unauthorized practice has arisen. The state courts have condemned the practice whereby the agency filed claims and forwarded them to attorneys of its own selection. ${ }^{41}$ The Virginia and New York State courts took jurisdiction over the objection that the activities complained of were connected solely with practice in the federal

${ }^{31}$ CaI. Gen. Laws (Deering, I93r) Act I460.

s WASH. REv. Stats. (Remington, 1932) \$191. ${ }^{33} I d$. at $\$ 5847-4$.

36 Va. Acts $\$ 1924$, c. 415 providing in effect that no person, firm or corporation shall assign to another any claim, or any interest therein for the purpose of having such assignee represent the claim in court.

${ }^{3}$ Bryce v. Gillespie, I60 Va. 137, 168 S. E. 653 (1933).

${ }^{36}$ People v. Securities Discount Corp., 279 Ill. App. 7o (1935), affd, 36r Ill. 55I, I98 N. E. 68I (1935).

${ }^{37}$ State v. James Sanford Agency, supra note Io.

State ex rel. Freebourn v. Merchants' Credit Service, supra note 2.

${ }^{3}$ N. Y. Penal Laws, $\$ 280$, as amended by Laws 1934, c. 534 , $\$ 3$; 18 PA. Stat. ANN (Purdon, 1930) $\$ 2504$ "It shall be unlawful for a collection agency, for the purposes of collecting or enforcing the payment thereof, directly or indirectly, to buy, take an assignment of, or to become in any manner interested in the buying or taking of an assignment of, any such claim."

"Bennett ex rel. New York County Lawyers' Ass'n v. Supreme Enf. Corp., 250 App. Div. 265, 293 N. Y. Supp. 870 (1937), aff'd, I I N. E. (2d) 315 (N. Y. 1937).

'Depew v. Wichita Ass'n of Credit Men, supra note 2; Meisel \& Co. v. National Jewelers' Bd. of Trade, supra note to (agency solicited appointment of self as trustee in bankruptcy); Richmond Ass'n of Credit Men v. Bar Ass'n, sutpra note 25. 
courts, on the ground, inter alia, that the activities of the domestic corporate agency were subject to supervision by its state of incorporation. In the same field drawing up of assignments for the benefit of creditors by the agencies has been condemned. ${ }^{42}$ The federal courts are split upon the question, which has not as yet been passed upon by the Supreme Court, except inferentially in the denial of certiorari in the Depew case. Three district court decisions tend to the attitude of the state courts set forth above, holding: (I) That a layman cannot represent more than one creditor in a bankruptcy proceeding; ${ }^{43}$ (2) That the participation in the election of a trustee by a collection agency is the practice of law; ${ }^{44}$ (3) That a trustee in bankruptcy elected by votes cast under powers of attorney held by himself, and obtained by soliciting creditors, should be removed. ${ }^{45}$ The circuit court of appeals of the second circuit, however, has upheld the solicitation of claims for collection, and the vote by the collection agent, as representative of the creditors, for himself as trustee. ${ }^{40}$ One district court, tempering its definition of practice of law by what it considers to be a practical consideration of the effect of the agency's work in the administration of bankrupt estates, has recently held that the agency might lawfully solicit and file claims in bankruptcy, and solicit and use powers of attorney for the purpose of electing trustees in bankruptcy. ${ }^{47}$ The court relied on its judicial knowledge that the intervention of a disinterested collection agency often expedited the administration of a bankrupt estate by arousing creditors from their customary apathy. The simplicity of the work under the Supreme Court rules of procedure and the close supervision thereof by the referees in bankruptcy were also influential factors in the decision. Contrast with this viewpoint, that taken by the court in In re Scott ${ }^{48}$ which stresses the fact that the solicitation of claims in bankruptcy is a growing evil, resulting in ill-advised bankruptcies, expensive and unnecessary receiverships and trustees whose primary duties are neither to the court nor to the creditors as a whole.

The picture painted at the present time by the statutes and decisions relative to collection agencies is one of confusion. Save where it is barred completely, it is apparent that the agency occupies a different status in each of the states in which it has received legislative or judicial attention. In a number of states the agencies have been limited to the mere collection of claims, without resort to the courts, and without association with lawyers. Under such restrictions the agency certainly cannot offer the public a complete collection service, possibly cannot afford to stay in business maintaining the limited service in which it may legally engage. ${ }^{49}$ In a number of

\footnotetext{
${ }^{12}$ Depew v. Wichita Ass'n of Credit Men, supra note 2; Clark v. Reardon, 104 S. W. (2d) 407 (Mo. App. 1937).

${ }^{4}$ In re Ploof Mach. Co., 243 Fed. 421 (S. D. Fla. 1916).

"In re Scott, 53 F. (2d) 89 (W. D. Mich. I93I).

"In re Dalsimer \& Co., 56 F. (2d) 644 (S. D. N. Y. 1932).

${ }^{4}$ In re Mayflower Hat Co., 65 F. (2d) 330 (C. C. A. 2d, r933).

${ }^{47}$ Rinderknecht v. Toledo Ass'n of Credit Men, 13 F. Supp. 555 (N. D. Ohio I935).

is Supra note 44 .

${ }^{43}$ Angstman, J., dissenting in State ex rel. Freebourn v. Merchants' Credit Service, 66 P. (2d) 337,350 (Mont. 1937), says: "As I read the majority opinion, its effect is to put all collecting agencies in Montana out of business."
} 
states the agency has been enabled to offer a fairly complete service, either on the basis of an assignment procedure, or by acting as the creditor's agent in the selection of an attorney. In many states the question has not as yet come before the courts. It is to be expected that the present campaign by bar associations against the practice of law by the agencies will result in the judicial or legislative settlement of the problem in most jurisdictions, but this process would be facilitated if the judicial opinions in the field were more illuminating as to the bases of decision.

The process of decision in most collection agency cases permits the liberal use of judicial discretion. In the absence of any hard and fast definition of "practice of law" the courts feel free to characterize any activity as constituting such practice without shedding much illumination on the question of why this is so. Typical of the generality of the opinions in this field is the following: "We . . . hold that the acts, transactions, and conduct of the defendants enumerated and contained in findings Nos. 3, 4, 5, and 6 are within the general understanding and definition of practicing law and should be enjoined." The North Carolina court cites as the general rule that "services of the sort usually furnished by lawyers to their clients" constitute the practice of law. ${ }^{51}$ This appears to be the best harmonization of the results of the decided cases. The legal profession has traditionally handled the collection of claims. The present decisions are making a certain part of that work their exclusive property.

It is clear from the above that the result of the decisions has been to restrict the activities of collection agencies. This trend has been explained as based upon a public policy to keep the handling of legal affairs in the hands of those specially trained for legal work and possessed of high moral character; and to maintain the confidential and personal relationship between attorney and client. ${ }^{52}$ The first branch of this argument is rather superficial in its application to the problem of the collection agency, in that it assumes some definite standard as to what constitutes legal affairs-which is just the question which must be decided. Actually this is merely a general explanation of why the courts hold illegal the practice of law by those other than lawyers. The second branch of the argument is more fundamental. That the activities of the collection agencies in most cases do involve at least a technical impairment of the traditional confidential and personal relationship between attorney and client seems clear. Not so clear is the policy which dictates that any impairment of this relationship whatsoever should constitute the unauthorized practice of law. The courts, however, uniformly seize upon any impairment as constituting practice of the law by a collection agency, and uniformly refrain from explaining how the particular impairment harms the public, the client, or the attorney.

In most opinions no mention is made of the possible benefit or detriment to the

\footnotetext{
${ }^{\infty}$ Depew v. Wichita Ass'n of Credit Men, I42 Kan. 403, 416, 49 P. (2d) 1041, 1049 (1935).

"1 State ex rel. Seawell v. Carolina Motor Club, 209 N. C. 624,184 S. E. 540 (1936). Accord, R. I. Pub. Laws 1935, c. $2190, \$ 45$, Creditors' Service Corp. v. Cummings, supra note I2.

${ }^{62}$ Note (1937) Io So. Calif. L. Rev. 491.
} 
business community of the complained of agency activities. In the Depew case a contention that the agency benefited the community was mentioned by the court only to be rejected as immaterial on the question of practice of law. The same treatment was accorded the contention that the legal profession was attempting to maintain a monopoly and prevent competition in the collection business. ${ }^{53}$ Economic protection of the legal profession may in fact be an underlying reason for the decisions but it is rarely made explicit. ${ }^{54}$ Two cases have taken a strictly practical approach to the problem and have reached diametrically opposite results-one condemning ${ }^{55}$ and the other upholding ${ }^{56}$ the collection agency practices complained of.

More decisions similar in approach to these last two are needed. If the problem is to determine what degree of impairment renders the intervention by the lay agency undesirable, then certainly a careful examination of the character and effect of the agencies' operations should be undertaken. The decisions should reflect a practical determination of whether the collection agency activities complained of require the technical training of the lawyer, whether the ethical standards of collection agencies are observed and are adequate to protect the public. Other questions too should be faced. Does intervention by the lay agency jeopardize the independence of the legal profession? Do the operations of the agencies stir up unnecessary litigation and result in the oppression of debtors? Can a distinction be taken between the activities of "good" and "bad" agencies, even though their general plans of operation be the same? How efficient a collection service could the creditor obtain if the agency were withdrawn from the field? A frank consideration of these questions would certainly be conducive to a better understanding of the problem.

\footnotetext{
${ }^{\infty}$ Depew v. Wichita Ass'n of Credit Men, supra note 2.

Es State ex rel. Freebourn v. Merchants' Credit Service, 66 P. (2d) 337, 344 (Mont. 1937) ("To excuse [collection agencies] from obeying the mandate of the statute or the unwritten rules which determine the character of the practice of lawyers acting in the same capacity, would be to impose an unjustifiable burden upon lawyers not imposed on individuals engaged in the same line of work.")

$\varpi$ In re Scott, supra note 44 .

${ }^{68}$ Rinderknecht v. Toledo Ass'n of Credit Men, supra note 46.
} 